OPEN ACCESS

Edited by:

Paola Bianchi,

IRCCS Ca 'Granda Foundation

Maggiore Policlinico Hospital, Italy

Reviewed by:

Elisa Fermo,

IRCCS Ca 'Granda Foundation

Maggiore Policlinico Hospital, Italy

*Correspondence:

Theodosia A. Kalfa

theodosia.kalfa@cchmc.org

Specialty section:

This article was submitted to

Red Blood Cell Physiology,

a section of the journal

Frontiers in Physiology

Received: 03 September 2019 Accepted: 04 October 2019

Published: 18 October 2019

Citation:

Chonat S, Risinger M, Sakthivel $H$,

Niss O, Rothman JA, Hsieh L,

Chou ST, Kwiatkowski JL, Khandros E, Gorman MF, Wells DT, Maghathe T, Dagaonkar N, Seu KG,

Zhang $K$, Zhang $W$ and Kalfa TA (2019) Corrigendum: The Spectrum of

SPTA1-Associated Hereditary Spherocytosis.

Front. Physiol. 10:1331

doi: 10.3389/fphys.2019.01331

\section{Corrigendum: The Spectrum of SPTA1-Associated Hereditary Spherocytosis}

\author{
Satheesh Chonat ${ }^{1,2}$, Mary Risinger ${ }^{3}$, Haripriya Sakthivel ${ }^{4}$, Omar Niss ${ }^{4,5}$, \\ Jennifer A. Rothman ${ }^{6}$, Loan Hsieh ${ }^{7}$, Stella T. Chou ${ }^{8,9}$, Janet L. Kwiatkowski ${ }^{8,9}$, \\ Eugene Khandros ${ }^{8,9}$, Matthew F. Gorman ${ }^{10}$, Donald T. Wells ${ }^{11}$, Tamara Maghathe ${ }^{4}$, \\ Neha Dagaonkar ${ }^{12}$, Katie G. Seu ${ }^{4}$, Kejian Zhang ${ }^{13}$, Wenying Zhang ${ }^{5,14}$ and \\ Theodosia A. Kalfa ${ }^{4,5 *}$
}

${ }^{1}$ Department of Pediatrics, Emory University School of Medicine, Atlanta, GA, United States, ${ }^{2}$ Aflac Cancer and Blood Disorders Center, Children's Healthcare of Atlanta, Atlanta, GA, United States, ${ }^{3}$ College of Nursing, University of Cincinnati, Cincinnati, $\mathrm{OH}$, United States, ${ }^{4}$ Cancer and Blood Diseases Institute, Cincinnati Children's Hospital Medical Center, Cincinnati, $\mathrm{OH}$, United States, ${ }^{5}$ Department of Pediatrics, University of Cincinnati College of Medicine, Cincinnati, $\mathrm{OH}$, United States, ${ }^{6}$ Duke University Medical Center, Durham, NC, United States, ${ }^{7}$ Division of Hematology, CHOC Children's Hospital and UC Irvine Medical Center, Orange, CA, United States, ${ }^{8}$ Division of Hematology, Children's Hospital of Philadelphia, Philadelphia, PA, United States, ${ }^{9}$ Department of Pediatrics, Perelman School of Medicine, University of Pennsylvania, Philadelphia, PA, United States, ${ }^{10}$ Kaiser Permanente Santa Clara Medical Center, Santa Clara, CA, United States, ${ }^{11}$ Dell Children's Medical Center, Austin, TX, United States, ${ }^{12}$ Genomics Analysis Facility, Institute for Genomic Medicine, Columbia University, New York, NY, United States, ${ }^{13}$ Coyote Bioscience Co., Ltd., San Jose, CA, United States, ${ }^{14}$ Laboratory of Genetics and Genomics, Division of Human Genetics, Cincinnati Children's Hospital Medical Center, Cincinnati, $\mathrm{OH}$, United States

Keywords: SPTA1, $\alpha$-spectrin, $\alpha^{\text {LEPRA, }}$, hereditary spherocytosis, next generation sequencing, hemolytic anemia, hydrops fetalis

\section{A Corrigendum on}

The Spectrum of SPTA1-Associated Hereditary Spherocytosis

by Chonat, S., Risinger, M., Sakthivel, H., Niss, O., Rothman, J. A., Hsieh, L., et al. (2019). Front. Physiol. 10:815. doi: 10.3389/fphys.2019.00815

In the original article, there was a mistake in Table $\mathbf{1}$ as published. The SPTA1 mutation of Allele 2 in Patient 1, is stated as "c.4294T>A (p.L1432*)." The correct mutation should read "c.4295del (p.L1432*)." The corrected Table 1 appears below.

The authors apologize for this error and state that this does not change the scientific conclusions of the article in any way. The original article has been updated.

\section{REFERENCES}

Bogardus, H., Schulz, V. P., Maksimova, Y., Miller, B. A., Li, P., Forget, B. G., et al. (2014). Severe nondominant hereditary spherocytosis due to uniparental isodisomy at the SPTA1 locus. Haematologica 99, e168-e170. doi: 10.3324/haematol.2014.110312

Copyright (c) 2019 Chonat, Risinger, Sakthivel, Niss, Rothman, Hsieh, Chou, Kwiatkowski, Khandros, Gorman, Wells, Maghathe, Dagaonkar, Seu, Zhang, Zhang and Kalfa. This is an open-access article distributed under the terms of the Creative Commons Attribution License (CC BY). The use, distribution or reproduction in other forums is permitted, provided the original author(s) and the copyright owner(s) are credited and that the original publication in this journal is cited, in accordance with accepted academic practice. No use, distribution or reproduction is permitted which does not comply with these terms. 
TABLE 1 | Genetic mutations and associated phenotype in HS due to SPTA1 mutations.

\begin{tabular}{|c|c|c|c|c|c|c|}
\hline Phenotype & Patient & Allele 1 & Allele 2 & $\begin{array}{l}\text { Age at time of report and } \\
\text { comments }\end{array}$ & Ektacytometry & $\begin{array}{l}\alpha \text {-spectrin in } \\
\text { RBC ghosts (\% } \\
\text { of control) }\end{array}$ \\
\hline & 2 & c.4339-99C > T & $\begin{array}{c}\text { C.5102A > T } \\
\left(p . L 1701^{*}\right)\end{array}$ & $\begin{array}{l}7 \text { year-old, chronic transfusion } \\
\text { requirement, improved with partial } \\
\text { splenectomy }\end{array}$ & .. & $64 \%$ \\
\hline & 4 & $\begin{array}{c}\text { Mutation } \\
\text { not identified }\end{array}$ & $\begin{array}{l}\text { Gross deletion } \\
\text { of SPTA1 }\end{array}$ & $\begin{array}{l}3.5 \text { year-old, RT-PCR demonstrated } \\
\text { significantly decreased } \alpha \text {-spectrin } \\
\text { expression; hemoglobin has } \\
\text { normalized after recent splenectomy }\end{array}$ & \multicolumn{2}{|c|}{ Not evaluable in a transfused sample } \\
\hline \multirow[t]{2}{*}{$\begin{array}{l}\text { GROUP II (patients 5-8) } \\
\text { Severe to moderately } \\
\text { severe, recessive HS }\end{array}$} & 5 & c. $4339-99 \mathrm{C}>\mathrm{T}$ & $\begin{array}{c}\text { c. } 1120 \mathrm{C}>\mathrm{T} \\
\left(\mathrm{p} \cdot \mathrm{R} 374^{\star}\right)\end{array}$ & $\begin{array}{l}4 \text { year-old, chronic transfusion } \\
\text { requirement for first three years with } \\
\text { improved pattern since. }\end{array}$ & \multicolumn{2}{|c|}{$\begin{array}{l}\text { Sample not provided after age } 3 \text {, } \\
\text { when transfusion-independent }\end{array}$} \\
\hline & 6 & c.4339-99C > T & c. $1351-1 G>T$ & $\begin{array}{l}7 \text { year-old, occasional transfusion } \\
\text { requirement, resolved after } \\
\text { splenectomy at } 5 \text { years of age }\end{array}$ & $\because:$ & $59 \%$ \\
\hline \multirow{3}{*}{$\begin{array}{l}\text { GROUP III (patients } \\
\text { 9-11) Life-threatening } \\
\text { anemia in utero leading } \\
\text { to fatal hydrops fetalis if } \\
\text { untreated (transfusion- } \\
\text { dependent, not } \\
\text { responding to } \\
\text { splenectomy) }\end{array}$} & 9 & c.4206delG (fs) & $\begin{array}{l}\text { c.4180delT (fs) in } \\
\text { haplotype with } \\
\text { c.6631C > T } \\
\text { (p.R2211C) }\end{array}$ & $\begin{array}{l}\text { Died at birth. Post-mortem diagnosis } \\
\text { from parental studies and DNA } \\
\text { extracted from liver tissue saved in } \\
\text { paraffin block }\end{array}$ & N/A & \\
\hline & 10 & c. $6788+11 \mathrm{C}>\mathrm{T}$ & c. $6788+11 \mathrm{C}>\mathrm{T}$ & $\begin{array}{l}11 \text { year-old, born prematurely at EGA } \\
\text { of } 33 \text { weeks with hydrops fetalis, } \\
\text { remained transfusion-dependent } \\
\text { even after splenectomy; now doing } \\
\text { well after matched sibling transplant }\end{array}$ & $\begin{array}{l}\text { Not evaluable in a } \\
\text { transfused sample (required } \\
\text { chronic transfusions up until } \\
\text { bone marrow transplant) }\end{array}$ & $\begin{array}{l}26 \% \text { (performed in } \\
\text { CD71+ cells) }\end{array}$ \\
\hline & 11 & $\begin{array}{l}\text { c.6154del } \\
\text { (p.Ala2052fs) }\end{array}$ & $\begin{array}{l}\text { c.6154del } \\
\text { (p.Ala2052fs) }\end{array}$ & $\begin{array}{l}2 \text { year-old, severe in-utero anemia } \\
\text { requiring five in-utero transfusions. } \\
\text { Born with severe neonatal } \\
\text { hyperbilirubinemia requiring exchange } \\
\text { transfusion. Remains } \\
\text { transfusion-dependent }\end{array}$ & $\begin{array}{l}\text { Not evaluable in a } \\
\text { transfused sample }\end{array}$ & \\
\hline
\end{tabular}

Of note, all the SPTA1 variants reported here except c.4339-99C > T ( $\left.\alpha^{L E P R A}\right)$ and c.2671C > T; p.R891* (Bogardus et al., 2014) have not been previously described. 